\title{
Spinal cord schistosomiasis
}

\section{Case report}

Flávio Leitão*, Djacir Figueiredo*, Daniel Figueiredo*, Dalgimar Bezerra de Menezes ${ }^{* *}$, Flávio Leitão Filho***, João Paulo Mattos ${ }^{\star * * *}$

Fortaleza General Hospital and Fortaleza Institute of Neurosurgery - Fortaleza, Ceara, Brazil

\section{ABSTRACT}

The authors present a case of spinal cord schistosomiasis which simulated a tumoral lesion determining spastic paraparesis with a sensitive-motor level at T1. The patient was treated with surgery, praziquantel and dexamethasone, with "restitutio ad integrum". Seven years later the patient presented recrudescence of the symptoms, without a good response to the medication and without a plausible explanation.

The authors wonder about the reasons of the low incidence of central nervous system schistosomosis in an endemic area such as the Northeast of Brazil. A brief review of the literature is done.

\section{KEY WORDS}

Schistosomiasis. Spinal cord schistosomiasis.

\section{RESUMO}

Neuroesquistossomose medular. Relato de caso

Os autores apresentam um caso de esquistossomose medular simulando processo tumoral, manisfestando-se com paraparesia espástica e nível sensitivo em T1. O tratamento cirúrgico, complementado pela administração de praziquantel e dexametasona, proporcionou recuperação total do quadro neurológico. Após sete anos, houve recidiva dos sintomas, de causa não totalmente esclarecida e sem resposta ao tratamento medicamentoso.

Chamam atenção à baixa incidência de neuroesquistossomose em regiões endêmicas, como o Nordeste do Brasil.

\section{PALAVRAS-CHAVE}

Esquistossomose. Esquistossomose medular. Neuroesquistossomose.

\section{Introduction}

Schistosomosis, schistosomiasis and bilharziosis are the names used to identify the disease caused by the Schistosoma or Schistosomo, the last name being a reverence to Theodor Bilharz, a German parasithologist, Professor of Cairo University and a studious of the matter. This disease is not new. The famous Ebers papiro refers to it, milleniums before the Christian $\mathrm{Era}^{11}$.

The etiologic agent is a plathelmint worm from the Trematoid class, Schistosomidea family. The importance of the disease is justified by the great number of people affected by it in the world - about 200 millions in 74 countries of Latin America, Africa and $\mathrm{Asia}^{20}$. In Brazil this number is 6 millions, and there are authors who suggest higher numbers, such as 13 millions $^{5}$ and 20 millions $^{17}$. The prevalence of the disease in the different Brazilian geographic regions is shown in the table 1.

\footnotetext{
* $\quad$ Professor of the Health Science Center (HSC) of the Ceara Federal University (CFU)

** Head of Pathologic Anatomy Service, Fortaleza General Hospital (FGH)

*** Neurosurgical Resident

**** Medical student of HSC of CFU
} 


\begin{tabular}{cc} 
Table 1 & \\
Prevalence of Schistosomiais & in Brazil \\
\hline Region & Prevalence (\%) \\
Southeast & 8,2 \\
Northeast & 7,2 \\
South & 1,9 \\
Centralwest & 1,9 \\
North & 1,2 \\
\hline
\end{tabular}

From: REY L: Basic of Medical Parasitology. RJ, Guanabara, 1992.

Central nervous system infestation by Schistosoma mansoni is rarely diagnosed ${ }^{13}$. It is very strange that only a few cases of spinal cord or cerebral ectoptical schistosomosis were reported in the Brazilian Northeast, since there is a great incidence of schistosomosis in this region of the Country. It may be due to an undernotification as well as to the fact that this complication of the disease has not been systematically searched. Another reason for the low number of cases of neuroschistosomiasis might be the host's immunologic response. When the relationship between the host and the Schistossoma is longer, higher will be the host's resistance to the toxicity of the eggs. In other words, the relationship with the Schistosoma creates antibodies, which blockade the toxic effects of the helminthic eggs.

Because of this immunologic response, the asymptomatic form of neuroschistosomiasis is more frequent than the symptomatic one ${ }^{7}$. In endemic zones, this diagnostic possibility should always be searched ${ }^{10}$.

Schistosoma may lead to granuloma like lesions in many parts of the central nervous system ${ }^{2}$. It has not well explained why in the central nervous system the $S$. mansoni is commonly ectopically located in the spinal cord, whereas the $S$. japonicum is preferably located in the brain ${ }^{15}$. The cerebral lesions have a worse prognosis leading to death ${ }^{1}$. There is a better prognosis for spinal cord lesions, known since 1905.

\section{Case report}

This 30-years-old man, born in an endemic area of Schistosomosis, where he lived for 25 years, arrived at the Hospital complaining about difficulty in urinating, lack of potentia coeundi and numbness of the legs during the previous three months. His complaints had begun one year before with an insidious evolution, without periods of remission or stagnation of the symptoms.

The clinical examination was basically normal. The neurological examination showed a spastic paraparesis with bilateral foot clonus and positive Babisnski sign and sensory deficit to touch and superficial pain up to the level of the nipples.

With the suspicion of thoracic spinal cord lesion, the patient was submitted to a positive contrast myelography which showed an obstruction to the contrast flow at the level of T1. The cerebrospinal fluid (CSF) was clear and colorless, with a normal cell count but with increased protein concentration. The blood laboratory exams were essentially normal, except for a slight increase of GPT and slight eosinophilia.

On August 8, 1985, the patient was submitted to a laminectomy from $\mathrm{T} 1$ to $\mathrm{T} 4$. By opening the dura mater it was found a hyperemic and bulged spinal cord; a posterior median myelotomy under microscopic vision demonstrated a fibrous, jelly, infiltrating grayish tissue which was removed; the dura mater was left opened.

The histopathologic examination showed a "schistosomose granuloma" (Fig. 1). Praziquantel, $50 \mathrm{mg} / \mathrm{kg} / \mathrm{day}$, and dexamethasone, $16 \mathrm{mg} /$ day, for 15 days were administered. Ten days after the surgery he was discharged from the hospital and in the follow up he presented a gradual return to normal status to the point that he could resume his routine activities.

On March 1992, seven years after his first hospital admission, the patient returned reporting a clinical picture similar to that presented previously. The rectal biopsy and the feces examination were negative for Schistosoma. The myelography with water-soluble contrast was inconclusive. Nuclear magnetic resonance (NMR) imaging showed a narrowing of the spinal canal at the level of the surgery previously done, without signs of recurrence of granuloma, raising the question of a gliotic process.

Up to the present he has not presented signs of neurological recuperation.

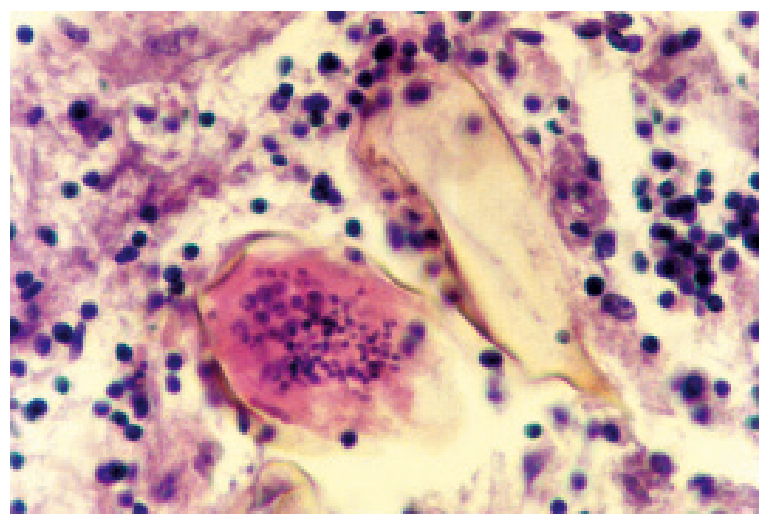

Figure 1 - Photomicrography of the surgical specimen. Nervous tissue with granulomatous lesion and Schistosoma eggs with the distinctive spicula. 


\section{Discussion}

The spinal cord involvement by $S$. mansoni is rarely diagnosed even in the Countries where the systemic diseases caused by this specie are endemic ${ }^{21}$. The present case is a male patient and according to the world literature the predominance of male patients is probably due to their heavy labor activity, which increases the intra-abdominal pressure more often. This facilitates the migration of the eggs into the veins of Batson's plexus $^{18,20}$.

The spinal cord schistosomiasis may present as a transverse myelitis-like syndrome $(29.4 \%)$, granulomatous or tumoral $(24.7 \%)$ as well as radicular or mixed $(44 \%)^{6,18,19}$. It may also present as a herniated disc or even hysteria ${ }^{8}$.

The disease may be controlled surgically or by the administration of praziquantel, oxaminiquine and corticosteroid $^{3,4,5}$. However it may present a spontaneous remission. It is worth reminding that the first two drugs act on the helminthes and not on its egg. Most of the authors use only one of the two drugs, although some of them defend the use of lower doses of the two drugs ${ }^{15}$. In fact, there is no uniformity concerning the treatment of the neuroschistosomiasis. Brito et al. ${ }^{7}$ suggest the administration of oxaminiquine in a single dose of $15 \mathrm{mg} / \mathrm{kg}$ or the praziquantel in a dose of 60 to $70 \mathrm{mg} / \mathrm{kg} /$ day during seven days, and Andrade ${ }^{4}$ suggests the praziquantel $0,5 \mathrm{~g} / \mathrm{kg} /$ day, during fourteen days. Galvão ${ }^{14}$ recommends the surgical resection for the sporadic cases of cerebral granulomas and the least possible handling if the lesion is in the spinal cord, that meaning a biopsy and decompressive laminectomy. The administration of dexamethasone or predinisone is mandatory as soon as the diagnosis is suspected.

The postoperative neurological recuperation presented by our patient might have been due to the decompressive laminectomy associated with the use of praziquantel and dexamethasone.

The literature shows that the search for specific antibodies in the cerebrospinal fluid (ELISA) would have definitive value ${ }^{12,16}$. However, Valença et al. ${ }^{22}$ showed in two cases that a positive result may be false when the blood-CSF barrier is altered allowing blood antibodies to be found in the CSF. Therefore, a positive immunologic reaction in the CSF is not conclusive for the diagnosis of neuroschistosomiasis. The NMR would be most reliable for the diagnosis.

The late worsening in our patient's condition may be considered as a tardy gliotic reaction to the inflammatory process caused by the granuloma, by the surgical manipulation, as well as to the fact that the dura mater was left opened.
A protocol is necessary in order to identify the real incidence of the spinal cord schistosomiasis, since its sporadic occurrence as reported is not justifiable in an endemic environment such as ours.

\section{Acknowledgement}

We are truly grateful to the professors Carlos Augusto Ciarlini Teixeira from the Neurology Department, Ivo Coelho and Yaci M de Neureda, from the Pathology Department of the Health Science Center at Ceara Federal University, for their support and cooperation in the present work.

\section{References}

1. ABATHGM, ABATH FGC, SILVA RG: Esquistossomose encefálica associada a outras lesões ectópicas. Neurobiol 48:3-18, 1985.

2. ALOE L, MORONI R, FIORI M, ANGELUCCI F: Chronic parasite infection in mice induyes brain graunulomas and differentially alters nerve growth factor levels and thermal responses in paws. Acta Neuropathol 92:300-5, 1996

3. AMR SS, SALAH I S: Schistosomiasis of the spinal cord in a Yemeni boy. A report of a case with brief review of the literature. Bull Soc Path Ex 82:685-9, 1989.

4. ANDRADE AN: Neuroesquistossomose. Arq Neuropsiquiat 44:275-9, 1986

5. ANDRADE AN, BASTOS CL: Esquistossomose mansônica cerebral. Arq Neuropsiquiat 47:199-204, 1989.

6. ANDRADE FILHO AS, REIS MG, SOUZA AL, MARTINS EL, SANTOS SR, ANCILON M, LIMA JM, QUEIROZ AC, GUIMARÃES MD, MORENO-CARVALHO AO, RAGO MF: Neuroesquistossomose mansônica: aspectos clínicos, laboratoriais e terapêuticos. Arq Neuropsiquiat 54:232-7, 1996.

7. BRITO JCF, SILVA JAG, SILVA EB, VIANA NO: Neuroesquistossomose medular; avaliação clínicolaboratorial de 5 casos. Arq Neuropsiquiat 50:207-11, 1992.

8. COSTA RO, GAMELEIRA FT, TENÓRIO RB, BOHRER LH, COSTA VB, PINTO Jr JM: Neuroesquistossomose em Alagoas. Rev Bras Neurol28: 79-86; 1992.

9. CUNHA AHGB, FURTADO G, CUNHA SHEB: Forma tumoral intramedular de infecção por Schistosoma mansoni. Arq Bras Neurocir 14:52-5, 1995.

10. DUPUIS MJM, ATROUNI S, DOOMS GC, GONSETTE RE: Schistosomiae medullaire; apport de l'imgenie par résonance magnetic. Presse Méd 19:1684, 1990. (Correspondence).

11. ENCICLOPÉDIA DELTA LAROUSSE: Rio de Janeiro, Delta Larousse, 1970, v5, pp 2540.

12. FERRARI TC, MOREIRA PR, OLIVEIRA RC, FERRARI ML, GALLINELLI G, CUNHA AB: The value of any enzyme - linked immunobosorbente - assay for the diagnosis schistosomiasis - mansoni myeloradiculopathy. Trans R Soc Trop Med Hyg 89:496-500, 1995. 
13. FERREIRA MS, COSTA-CRUZ JM, GOMES MA: Esquistossomose do sistema nervoso central; relato de um caso. Arq Neuropsiquiat 48:371-5, 1997.

14. GALVÃO ACR: Como eu trato neuroesquistossomose. In: Machado LR, Nóbrega JPS, Livramento JA, SpinaFrança A (eds): Neuroinfecção 94. São Paulo, Clínica Neurológica HC/FMUSP, 1994, pp 205-8.

15. HERSKOWITZ A: Spinal cord involvement with Schistosoma mansoni; case report. J Neurosurg 36:494-8, 1972.

16. PAMMENTER MD, HARIBAAI HC, EPSTEIN SR, ROUSSOUW EJ, BHIGJEE AI, BILL PL: The value of immunological approach to the diagnosis of schistossomal myelopathy. Am J Trop Med Hyg 44:32935, 1991.

17. PEREGRINO AJP: Neuroesquistossomose; quando e como investigo. In: Machado LR, Nóbrega JPS, Livramento JKA, Spina França A (eds): Neuroinfecção 94. São Paulo, Clínica Neurológica HC/FMUSP, 1994, pp 265-268.

18. PEREGRINO AJP, OLIVEIRA SP, PORTO AS, SANTOS LA, MENEZES EE, SILVAA, BRITO AL, PINHEIRO SP, PINHEIRO S, DIAS AB: Meningomielorradiculite por Schistosoma mansoni; Protocolo de Investigação e Registro de 21 (vinte e um) casos. Arq Neuropsiquiat 46:49-60, 1988.
19. PEREIRA CU, LEÃO JDBC, BARRETO AS, AYALA MAR, MENEZES ANO: Esquistossomose medular na infância. J Bras Neurocirurg 7:35-8, 1996.

20. PITELA JE: Neuroschistosomiasis. Brain Pathol 7:64962, 1997.

21. SHAIL E, SIQUEIRA EB, HAIDER A, HALLIM M: Neuroschistosomiasis myelopathy case report. $\mathrm{Br} J$ Neurosurg 8:239-42, 1994.

22. VALENÇA MM, BARROS AC, ATAIDE JR, ASANO N, VALENÇA M, TRAVASSOS F, MELLO RV: Neuroesquistossomose; aspectos epidemiológicos e critério diagnóstico. Neurobiologia 55:145-52, 1992.

Original recebido em dezembro de 1997 Aceito para publicação em setembro 1998

\section{Endereço para correspondência:}

Flávio Leitão

Rua Filadélfia, 1.390

CEP 60811-120 - Água Fria - Fortaleza, CE 